Article

\title{
Traffic-Related Trace Element Accumulation in Roadside Soils and Wild Grasses in the Qinghai-Tibet Plateau, China
}

Guanxing Wang ${ }^{1}$, Xuedong Yan ${ }^{1, *}$, Fan Zhang ${ }^{2}$, Chen Zeng ${ }^{2}$ and Dan Gao ${ }^{1}$

1 MOE Key Laboratory for Urban Transportation Complex Systems Theory and Technology, Beijing Jiaotong University, Beijing 100044, China; E-Mails: 12121009@bjtu.edu.cn (G.W.); 11121095@bjtu.edu.cn (D.G.)

2 Key Laboratory of Tibetan Environment Changes and Land Surface Processes, Institute of Tibetan Plateau Research, Chinese Academy of Sciences, Beijing 100101, China;

E-Mails: zhangfan@itpcas.ac.cn (F.Z.); zengchen@itpcas.ac.cn (C.Z.)

* Author to whom correspondence should be addressed; E-Mail: xdyan@bjtu.edu.cn; Tel./Fax: +86-10-5168-4602.

Received: 8 October 2013; in revised form: 17 December 2013 / Accepted: 23 December 2013 / Published: 30 December 2013

\begin{abstract}
This research examines traffic-source trace elements accumulations and distributions in roadside soils and wild grasses in the Qinghai-Tibet Plateau. A total of 100 soil samples and 100 grass samples including Achnatherum splendens, Anaphalis nepalensis, Artemisia sphaerocephala, Carex moorcroftii, Iris lacteal, Kobresia myosuroides, Oreosolen wattii, Oxytropis ochrocephala and Stellera chamaejasme were collected at 100 sites from different road segments. The contents of metals and metalloids, including $\mathrm{Cu}$, $\mathrm{Zn}, \mathrm{Cd}, \mathrm{Pb}, \mathrm{Cr}, \mathrm{Co}, \mathrm{Ni}$ and $\mathrm{As}$, in the soil and grass samples were analyzed using ICP-MS. The total mean concentrations of the eight trace elements in soils are $\mathrm{Cu}(22.84 \mathrm{mg} / \mathrm{kg})$, $\mathrm{Zn} \quad(100.56 \mathrm{mg} / \mathrm{kg}), \quad \mathrm{Cd} \quad(0.28 \mathrm{mg} / \mathrm{kg}), \quad \mathrm{Pb} \quad(28.75 \mathrm{mg} / \mathrm{kg}), \quad \mathrm{Cr} \quad(36.82 \mathrm{mg} / \mathrm{kg})$, Co $(10.24 \mathrm{mg} / \mathrm{kg})$, Ni (32.44 mg/kg) and As (21.43 mg/kg), while in grasses are $\mathrm{Cu}(9.85 \mathrm{mg} / \mathrm{kg}), \mathrm{Zn}(31.47 \mathrm{mg} / \mathrm{kg}), \mathrm{Cd}(0.05 \mathrm{mg} / \mathrm{kg}), \mathrm{Pb}(2.06 \mathrm{mg} / \mathrm{kg}), \mathrm{Cr}(14.16 \mathrm{mg} / \mathrm{kg})$, Co $(0.55 \mathrm{mg} / \mathrm{kg})$, Ni (4.03 mg/kg) and As (1.33 mg/kg). The metal and metalloid concentrations in the nine grass species were all below the critical values of hyperaccumulators. The mean values and Multivariate Analysis of Variance (MANOVA) results indicate that: (1) the concentrations of the trace elements in the soils are higher than those in the grasses, (2) the concentrations of $\mathrm{Cu}, \mathrm{Zn}, \mathrm{Cd}, \mathrm{Pb}$ in the soils decrease as the roadside distance increases, (3) the concentrations of trace elements in the grasses are
\end{abstract}


the highest at $10 \mathrm{~m}$ from the road edge, (4) the higher the traffic volume, the higher the concentrations of the trace elements in the roadside soils and grasses, and (5) when the land cover is meadow, the lower the sand content in the soil, the lower the trace element concentrations. With a trace element's bioavailability represented by its transfer factor (TF) from the soil to the grass, the TFs of the eight trace elements are not in the same orders for different grass species.

Keywords: Qinghai-Tibet Plateau; trace element; roadside soil; roadside grass; transfer factor (TF)

\section{Introduction}

Soils are recognized to be major sinks for various of contaminants [1,2]. Except for organic contaminants, heavy metals such as $\mathrm{Cu}, \mathrm{Zn}, \mathrm{Pb}, \mathrm{Cd}, \mathrm{Cr}, \mathrm{Co}$, $\mathrm{Ni}$ and the metalloid As (collectively known as metal(loid)s or trace elements) [1] in soils have become a growing concern in recent years because of their toxicity and persistency in the environment [3]. Traffic activity is the main source of metal(loid)s emissions to roadside soils [4-6] and higher metal(loid) concentrations can be found in the soils and road dust along the roads with heavy traffic $[3,6,7]$.

The metal(loid)s can be absorbed by plants, and possibly harm human health through the food chain [8]. Some metals, such as $\mathrm{Cu}, \mathrm{Zn}$ and so on, are necessary for plants, and they play a very important role in plants growth. However, trace elements in soils will harm plants when their concentrations are over certain critical values. Despite this, some kinds of plant species called hyperaccumulators can grow well in soils with high concentrations of trace elements, such as in mining areas $[9,10]$. In recent decades, scholars have found many hyperaccumulators in wild areas [11]. Hyperaccumulators can be used to clean the metal(loid)s in polluted soil $[12,13]$. Therefore, research on trace element accumulation caused by road traffic and their uptake by plants are of great significance to the region's environmental protection and human health safety.

Called as "the Roof of the World" and "the Third Pole of the World", the Qinghai-Tibet Plateau is the highest and biggest plateau of the World, occupying an area of 2.5 million $\mathrm{km}^{2}$ and with an average elevation of over 4,000 $\mathrm{m}$ above sea level (a.s.1.) [8,14-16]. With the development of the Chinese economy and improved transportation conditions, its unique geographical position and special climate environment have attracted more and more tourists. The environment has been gradually affected by this activity. Because it is rarely affected by other anthropogenic activities [8], such as industrial activities, traffic is the main source of metal(loid)s in soil along the roads there. In other words, the Qinghai-Tibet Plateau is a suitable place to investigate the relationship between traffic and related environment contamination.

In this study, grass samples were collected from the same sites where the soil samples were collected. The metal(loid) concentrations in the soils and the relationship to the roadside distance has been discussed in a previous study of Yan et al. [8], and this research will mainly discuss: (1) the correlation of the metal(loid)s in soils and grasses, (2) the relationship between roadside distance, land cover, traffic volume and the concentrations of the trace elements in soils, as well as in 
grasses, (3) whether the grasses selected in this research are hypheraccumulators, and (4) the transfer factors $(\mathrm{TF})$ of the trace elements from the soil to the grass.

\section{Materials and Methods}

\subsection{Study Area}

One hundred samples were collected from 20 sampling sections along three roads as shown in Figure 1 (coordinates: $30^{\circ} 15^{\prime} 0.51^{\prime \prime} \mathrm{N}-36^{\circ} 4^{\prime} 2.24^{\prime \prime} \mathrm{N}, 90^{\circ} 39^{\prime} 13.13^{\prime \prime E}-100^{\circ} 33^{\prime} 11.95^{\prime \prime E}$; Altitude: $2,771 \mathrm{~m}-5,000 \mathrm{~m}$ a.s.1.) on the Qinghai-Tibet Plateau from July to August 2011. The profiles of the sampling sections are shown in Table 1. The three roads are the \#214 national highway (G214) from Xining to Qingshuihe, the \#308 provincial highway (S308) from Qingshuihe to Putongquan and the \#109 national highway (G109) from Putongquan to Lhasa. G109 is the most important transportation route into the Qinghai-Tibet Plateau. G214 is named the most beautiful national highway due to the biodiversity, geological diversity, and landscape diversity along the road. S308 is a link between G214 and G109. Some sections of S308 were damaged in the 2010 Yushu earthquake and have been repaired afterwards. During the sampling time period, traffic observation was implemented by counting the traffic volume for $1 \mathrm{~h}$. Accordingly, the rank of the traffic volumes of the three roads is speculated as $\mathrm{G} 214>\mathrm{G} 109>\mathrm{S} 208$.

Figure 1. Location of the three roads and sampling sites.

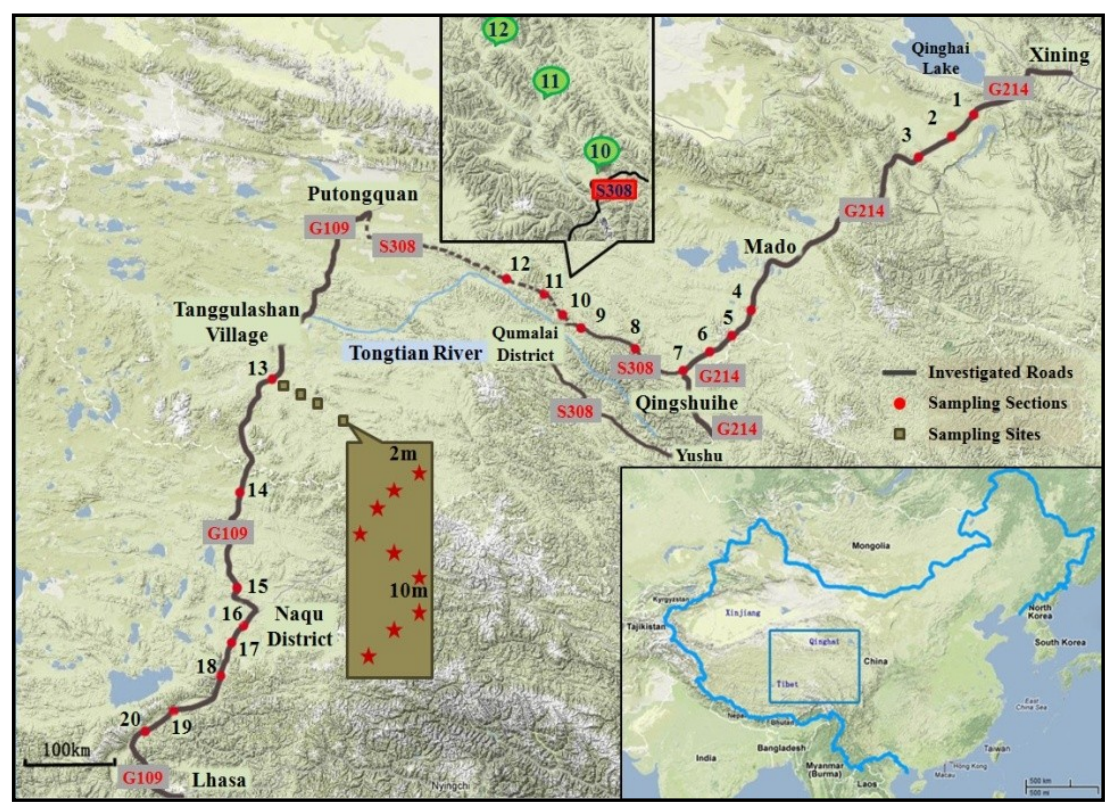

Table 1. Sampling section profiles.

\begin{tabular}{ccccc}
\hline Road & G109 & \multicolumn{2}{c}{ S308 } & G214 \\
\hline $\begin{array}{c}\text { No. of the } \\
\text { road sections }\end{array}$ & $1-7$ & $8-9$ & $10-12$ & $13-20$ \\
$\begin{array}{c}\text { Traffic Volume } \\
\text { Altitude (m a.s.l.) }\end{array}$ & $\begin{array}{c}\text { Medium } \\
3,771-4,500\end{array}$ & $\begin{array}{c}\text { Medium } \\
4,000-4,500\end{array}$ & Low & High \\
\hline
\end{tabular}




\subsection{Soil Sampling and Processing}

As shown in Figure 1, the distance between each of the 20 sampling sections is $20 \mathrm{~km}$ at least. For each section, five sampling sites were chosen at the distance of $0 \mathrm{~m}, 10 \mathrm{~m}, 30 \mathrm{~m}, 50 \mathrm{~m}$ and $100 \mathrm{~m}$ respectively from the sampling site perpendicular to the road edge. At each site, 8-10 sub-samples were taken in an "S-shape" pattern in a $10 \mathrm{~m} \times 2 \mathrm{~m}$ plot and evenly mixed [16]. A ditch of $5 \mathrm{~cm}$ in depth and $10 \mathrm{~cm}$ in diameter was dug for each sub-sample. After digging and mixing, the soil sample was put into a zip lock bag.

A total of 100 topsoil samples were collected. In order to analyze the correlation between trace elements and other conditions, three independent variables (DIST, LAND COVER and VOLUME) were recorded during sample collection. The sample size and description of variables related to the soil samples are shown in Table 2, in which $\mathrm{N}$ represents the number of samples.

Table 2. Sample size and description of variables related to the soil samples.

\begin{tabular}{|c|c|c|c|}
\hline Independent Variable & $\mathbf{N}$ & Variable Definition & Discrete Level \\
\hline \multirow{5}{*}{ DIST } & 20 & & Level 1: $0 \mathrm{~m}$ \\
\hline & 20 & The distance from the & Level 2: $10 \mathrm{~m}$ \\
\hline & 20 & sampling location & Level 3: $30 \mathrm{~m}$ \\
\hline & 20 & perpendicular to the road edge & Level 4: $50 \mathrm{~m}$ \\
\hline & 20 & \multirow{4}{*}{$\begin{array}{l}\text { Land cover different types of } \\
\text { land cover }\end{array}$} & Level 5: $100 \mathrm{~m}$ \\
\hline \multirow{3}{*}{ LAND COVER } & 45 & & Level 1: Meadow soil \\
\hline & 30 & & Level 2: High sandy meadow soil \\
\hline & 25 & & Level 3: Low sandy meadow soil \\
\hline \multirow{3}{*}{ VOLUME } & 40 & \multirow{3}{*}{ Three levels of traffic volume } & $\begin{array}{l}\text { Level 1: HIGH_-traffic volume above } \\
200 \text { vehicles per hour; }\end{array}$ \\
\hline & 15 & & $\begin{array}{l}\text { Level 2: LOW-traffic volume below } \\
50 \text { vehicles per hour; }\end{array}$ \\
\hline & 45 & & $\begin{array}{l}\text { Level 3: MEDIUM- traffic volume } \\
\text { between } 50 \text { and } 200 \text { vehicles per hour. }\end{array}$ \\
\hline
\end{tabular}

In the laboratory, the soil samples were air dried and milled by an agate mortar to pass through a $<0.15 \mathrm{~mm}$ nylon sieve. For metal analyzing, $0.3 \pm 0.0001 \mathrm{~g}$ of soil sample was taken in digestion tube with $9.25 \mathrm{~mL}$ of acid mixtures $\left(6 \mathrm{~mL} \mathrm{HNO}_{3}+3 \mathrm{~mL} \mathrm{HCL}+0.25 \mathrm{~mL} \mathrm{H}_{2} \mathrm{O}_{2}\right)$ added. The digestion tube was then put in an automatic microwave and heated gradually to $120^{\circ} \mathrm{C}$, holding for $5 \mathrm{~min}$, then to $160{ }^{\circ} \mathrm{C}$, holding for another $5 \mathrm{~min}$, and at last to $190{ }^{\circ} \mathrm{C}$, holding for $40 \mathrm{~min}$. After complete digestion, the extract was first diluted to $50 \mathrm{~mL}$ with deionized water, and then filtered. One $\mathrm{mL}$ of the filtered dilution was then diluted $10 \mathrm{~mL}$. Consequently, the concentrations of trace elements $(\mathrm{Cu}$, $\mathrm{Zn}, \mathrm{Cd}, \mathrm{Pb}, \mathrm{Cr}, \mathrm{Co}, \mathrm{Ni}$ and $\mathrm{As}$ ) were determined using the Inductively Coupled Plasma-Mass Spectrometry (ICP-MS, Thermo X Series 2, Thermo Fisher Scientific Inc., Waltham, MA, USA). In every batch of 40 samples for ICP-MS analyze there were two (5\%) blank reagents and two (5\%) standard reference soil materials (The National Standard Substance GBW-07407 and Soil Standard Reference Sample No. GSS-7) included for quality control. The relative standard deviation was less than $10 \%[16]$. 


\subsection{Grass Sampling and Processing}

As shown in Figure 2, nine species of grasses (Achnatherum splendens, Anaphalis nepalensis, Artemisia sphaerocephala, Carex moorcroftii, Iris lacteal, Kobresia myosuroides, Oreosolen wattii, Oxytropis ochrocephala and Stellera chamaejasme) were selected in this study, with consideration of the following two primary factors: (1) most of these grasses are endemic plants in the Qinghai-Tibet Plateau; (2) the grasses are abundant at the sampling site. A total of 100 grass samples were collected using a wood scissor from the same sites where the soil samples were collected. The sample size and description of variables related to each grass sample are shown in Table 3.

Figure 2. Photos of the selected grass species.

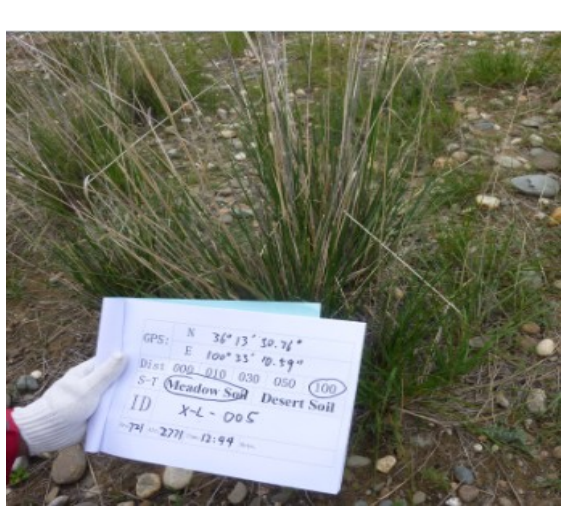

Achnatherum splendens
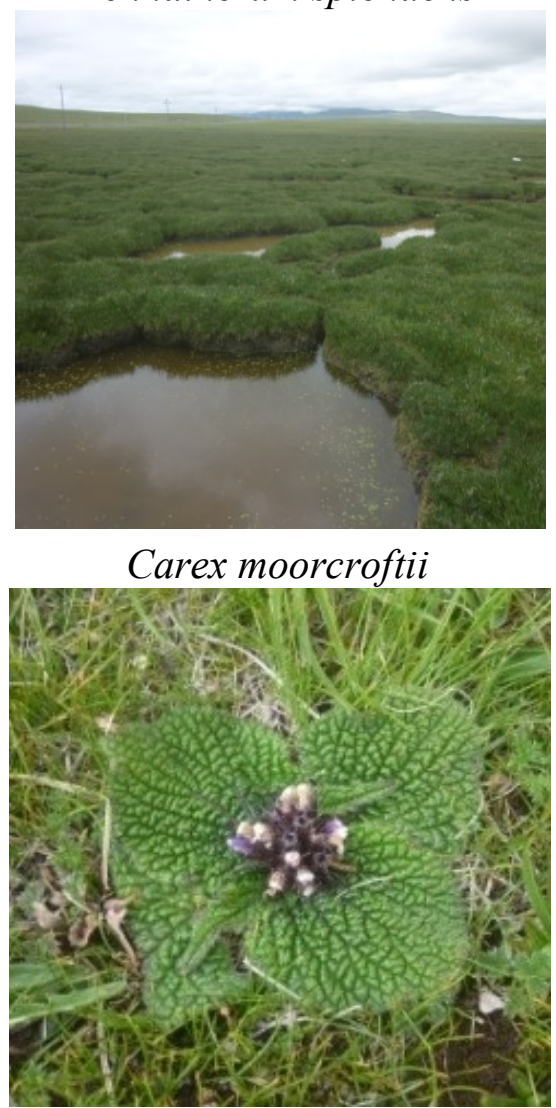

Oreosolen wattii

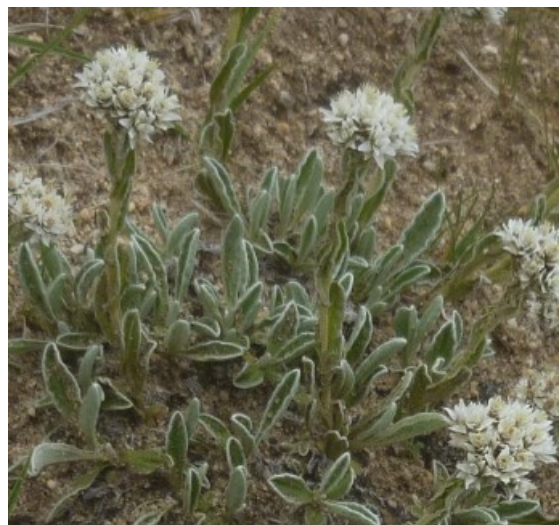

Anaphalis nepalensis

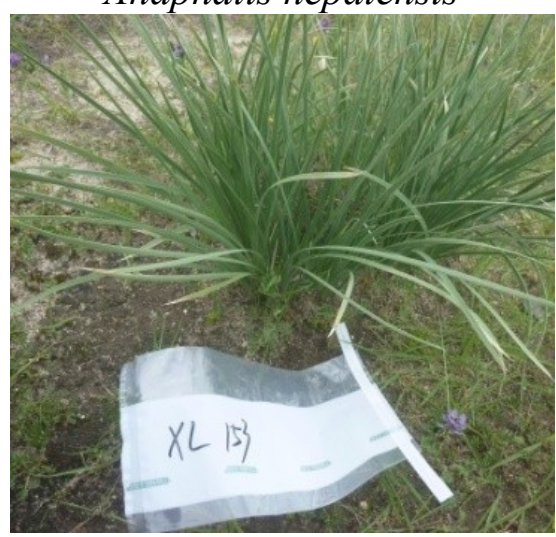

Iris lactea

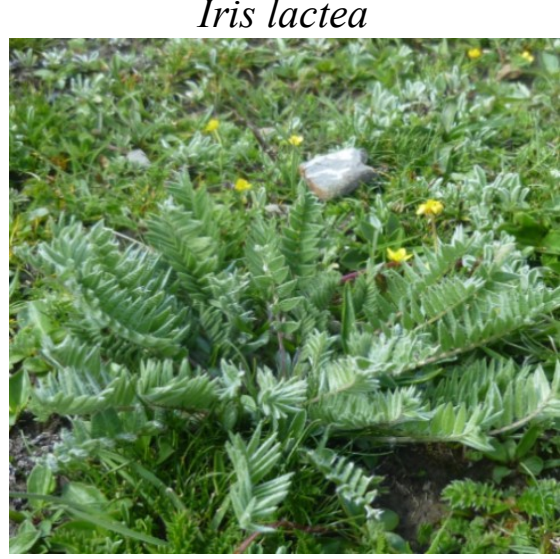

Oxytropis ochrocephala
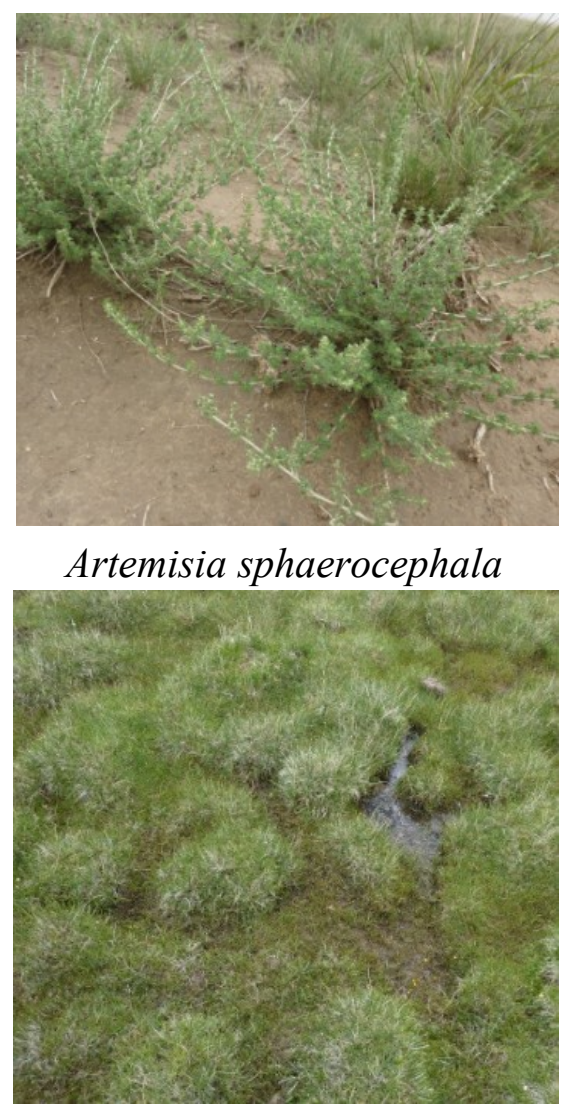

Kobresia myosuroides

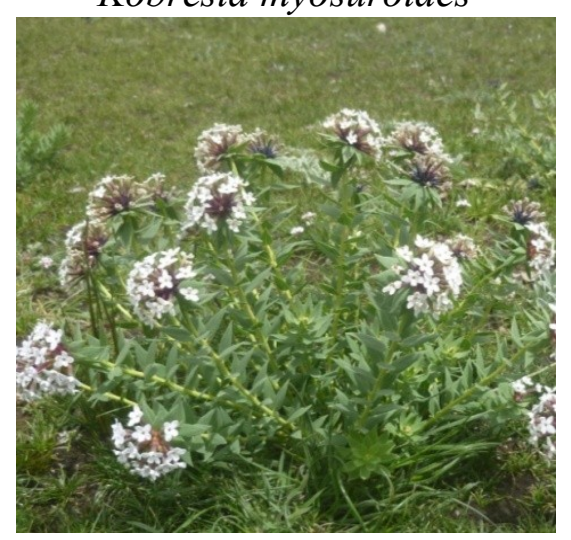

Stellera chamaejasme 
Table 3. Sample size and description of variables related to each grass sample.

\begin{tabular}{|c|c|c|c|c|c|c|c|c|c|c|}
\hline \multicolumn{2}{|c|}{ Name of the Grasses } & $\begin{array}{c}\text { Achnatherum } \\
\text { splendens }\end{array}$ & $\begin{array}{l}\text { Anaphalis } \\
\text { nepalensis }\end{array}$ & $\begin{array}{c}\text { Artemisia } \\
\text { sphaerocephala }\end{array}$ & $\begin{array}{c}\text { Carex } \\
\text { moorcroftii }\end{array}$ & Iris lactea & $\begin{array}{c}\text { Kobresia } \\
\text { myosuroides }\end{array}$ & Oreosolen wattii & $\begin{array}{c}\text { Oxytropis } \\
\text { ochrocephala }\end{array}$ & $\begin{array}{c}\text { Stellera } \\
\text { chamaejasme }\end{array}$ \\
\hline \multicolumn{2}{|c|}{ Family } & Gramineae & Compositae & Compositae & Cyperaceae & Iridaceae & Cyperaceae & Scrophulariaceae & Fabaceae & Thymelaeaceae \\
\hline \multicolumn{2}{|c|}{ Genus } & Achnatherum & Anaphalis & Artemisia & Carex & Iris & Kobresia & Oreosolen & Oxytropis & Stellera \\
\hline \multirow{5}{*}{ DIST } & $0 \mathrm{~m}$ & 1 & 4 & 1 & 3 & 1 & 4 & 1 & 4 & 1 \\
\hline & $10 \mathrm{~m}$ & 1 & 4 & 1 & 3 & 1 & 4 & 1 & 4 & 1 \\
\hline & $30 \mathrm{~m}$ & 1 & 4 & 1 & 3 & 1 & 4 & 1 & 4 & 1 \\
\hline & $50 \mathrm{~m}$ & 1 & 4 & 1 & 3 & 1 & 4 & 1 & 4 & 1 \\
\hline & $100 \mathrm{~m}$ & 1 & 4 & 1 & 3 & 1 & 4 & 1 & 4 & 1 \\
\hline \multirow{2}{*}{ LAND } & Level 1 & 0 & 5 & 0 & 15 & 0 & 15 & 5 & 5 & 0 \\
\hline & Level 2 & 5 & 10 & 0 & 0 & 0 & 5 & 0 & 5 & 5 \\
\hline \multirow{2}{*}{ COVER } & Level 3 & 0 & 5 & 5 & 0 & 5 & 0 & 0 & 10 & 0 \\
\hline & HIGH & 0 & 15 & 0 & 5 & 5 & 5 & 5 & 0 & 5 \\
\hline \multirow[t]{2}{*}{ VOLUME } & LOW & 0 & 5 & 0 & 0 & 0 & 5 & 0 & 5 & 0 \\
\hline & MEDIUM & 5 & 0 & 5 & 10 & 0 & 10 & 0 & 15 & 0 \\
\hline \multicolumn{2}{|c|}{ TOTAL } & 5 & 20 & 5 & 15 & 5 & 20 & 5 & 20 & 5 \\
\hline
\end{tabular}


Grass samples were firstly washed with deionized water, dried at $100{ }^{\circ} \mathrm{C}$ for $24 \mathrm{~h}$, then grounded into powder. $0.3 \pm 0.0001 \mathrm{~g}$ of sub-samples were digested. The analysis process of trace elements in grasses is the same as that in soil samples. For quality control during the trace elements analysis, $5 \%$ blank reagent samples and 5\% standard reference plant material samples (The national standard substance GBW-10011, CRM Wheat: No. GSB-2) were randomly added to the 100 grass samples. The relative standard deviation was less than $10 \%$.

\subsection{Data Analysis Methods}

Multivariate Analysis of Variance (MANOVA), Pearson correlation analysis, principal component analysis and cluster analysis were carried out using SPSS 20.0 package (IBM, Armonk, NY, USA). The significant affect of the independent variables (DIST, LAND COVER, VOLUME, and PLANT TYPE) on the eight trace elements in soils and plants is analyzed by MANOVA. Pearson Correlation analysis was used to derive statistical correlations and co-variation between trace elements. Sources discrimination of the eight trace elements in soil was performed by principal component analysis and cluster analysis.

The Transfer Factor (TF) represents the bioavailability of one trace element from soil to grass [16-18] calculated using Equation (1):

$$
\mathrm{TF}=\frac{C_{G}}{C_{S}}
$$

where $C_{G}$ is the concentration of a trace element in grass, and $C_{S}$ is the concentration of the trace element in the corresponding soil.

\section{Results and Discussion}

\subsection{Trace Element Concentrations in Roadside Soil and Corresponding Grasses}

Tables 4 and 5 summarize the basic statistical descriptions of the trace element concentrations $(\mathrm{mg} / \mathrm{kg})$ in roadside soils and corresponding grasses, respectively. As shown in Table 4, the total mean values of $\mathrm{Cu}(22.84 \mathrm{mg} / \mathrm{kg}), \mathrm{Zn}(100.56 \mathrm{mg} / \mathrm{kg}), \mathrm{Cd}(0.28 \mathrm{mg} / \mathrm{kg}), \mathrm{Pb}(28.75 \mathrm{mg} / \mathrm{kg}), \mathrm{Ni}(32.44 \mathrm{mg} / \mathrm{kg})$ and As $(21.43 \mathrm{mg} / \mathrm{kg})$ in soils were a little higher than the background values [19] except for $\mathrm{Cr}(36.82 \mathrm{mg} / \mathrm{kg})$ and Co $(10.24 \mathrm{mg} / \mathrm{kg})$, which means that there has been some accumulation in the roadside soil. The concentrations are a little higher than the $\mathrm{Zn}(67.23 \mathrm{mg} / \mathrm{kg}), \mathrm{Cd}(0.17 \mathrm{mg} / \mathrm{kg})$, $\mathrm{Pb}(24.37 \mathrm{mg} / \mathrm{kg}), \mathrm{Ni}(27.53 \mathrm{mg} / \mathrm{kg})$ and a little lower than the $\mathrm{Cu}(23.33 \mathrm{mg} / \mathrm{kg}), \mathrm{Cr}(57.77 \mathrm{mg} / \mathrm{kg})$ and Co $(11.53 \mathrm{mg} / \mathrm{kg})$ in Zhang's study along the Qinghai-Tibet railway [20]. Except for $\mathrm{Pb}$ and $\mathrm{As}$, the concentrations of $\mathrm{Cu}, \mathrm{Cd}, \mathrm{Cr}$ and $\mathrm{Ni}$ are lower than those in Toronto, on Canada in Wiseman's research [1]. What's more, in Chen's research [4] on some roadsides in Beijing (the capital of China), the concentrations of $\mathrm{Cu}(29.7 \mathrm{mg} / \mathrm{kg}), \mathrm{Pb}(35.4 \mathrm{mg} / \mathrm{kg})$ and $\mathrm{Cr}(61.9 \mathrm{mg} / \mathrm{kg})$ were higher than those in this research, while lower for $\mathrm{Zn}(92.1 \mathrm{mg} / \mathrm{kg}), \mathrm{Cd}(0.215 \mathrm{mg} / \mathrm{kg}), \mathrm{Ni}(26.7 \mathrm{mg} / \mathrm{kg})$ and As $(8.1 \mathrm{mg} / \mathrm{kg})$. 
Table 4. Descriptive Statistics of Trace Element Concentrations in Roadside Soil (mg/kg).

\begin{tabular}{|c|c|c|c|c|c|c|c|c|c|c|c|c|c|c|c|c|c|}
\hline & & \multicolumn{2}{|c|}{$\mathrm{Cu}-\mathrm{S}$} & \multicolumn{2}{|c|}{ Zn-S } & \multicolumn{2}{|c|}{ Cd-S } & \multicolumn{2}{|c|}{ Pb-S } & \multicolumn{2}{|c|}{$\mathrm{Cr}-\mathrm{S}$} & \multicolumn{2}{|c|}{ Co-S } & \multicolumn{2}{|c|}{ Ni-S } & \multicolumn{2}{|c|}{ As-S } \\
\hline & & Mean & S.D. & Mean & S.D. & Mean & S.D. & Mean & S.D. & Mean & S.D. & Mean & S.D. & Mean & S.D. & Mean & S.D. \\
\hline \multirow{6}{*}{ DIST } & $0 \mathrm{~m}$ & 26.80 & 5.02 & 114.57 & 32.41 & 0.43 & 0.40 & 41.83 & 31.64 & 37.48 & 11.01 & 10.96 & 2.01 & 37.09 & 24.38 & 21.99 & 4.91 \\
\hline & $10 \mathrm{~m}$ & 22.74 & 4.04 & 104.68 & 26.22 & 0.28 & 0.13 & 28.85 & 12.97 & 37.37 & 10.14 & 10.30 & 1.88 & 31.66 & 8.40 & 22.03 & 6.36 \\
\hline & $30 \mathrm{~m}$ & 22.48 & 4.14 & 98.86 & 16.72 & 0.26 & 0.12 & 25.76 & 9.21 & 37.59 & 9.14 & 10.29 & 1.73 & 32.11 & 7.20 & 21.89 & 6.36 \\
\hline & $50 \mathrm{~m}$ & 20.90 & 4.35 & 93.01 & 16.04 & 0.22 & 0.09 & 24.64 & 9.14 & 34.81 & 6.07 & 9.89 & 1.77 & 30.49 & 5.83 & 20.79 & 5.93 \\
\hline & $100 \mathrm{~m}$ & 21.28 & 4.69 & 91.68 & 14.25 & 0.22 & 0.08 & 22.67 & 7.56 & 36.84 & 7.81 & 9.74 & 1.86 & 30.85 & 5.19 & 20.43 & 5.71 \\
\hline & Level 1 & 21.35 & 4.43 & 93.49 & 12.06 & 0.24 & 0.07 & 23.98 & 9.37 & 37.89 & 11.56 & 9.86 & 1.86 & 32.46 & 9.07 & 19.01 & 6.00 \\
\hline \multirow{2}{*}{$\begin{array}{l}\text { LAND } \\
\text { COVER }\end{array}$} & Level 2 & 24.47 & 4.85 & 113.05 & 31.57 & 0.36 & 0.33 & 39.48 & 25.38 & 37.49 & 6.09 & 10.38 & 1.10 & 30.98 & 4.71 & 24.42 & 4.52 \\
\hline & Level 3 & 23.57 & 4.98 & 98.29 & 22.13 & 0.26 & 0.18 & 24.46 & 12.42 & 34.09 & 5.00 & 10.74 & 2.44 & 34.16 & 21.36 & 22.17 & 5.03 \\
\hline \multirow{3}{*}{ VOLUME } & HIGH & 21.65 & 5.30 & 110.49 & 31.30 & 0.35 & 0.32 & 40.76 & 23.09 & 39.75 & 11.60 & 9.83 & 1.92 & 32.71 & 10.25 & 23.13 & 7.16 \\
\hline & MEDIUM & 24.04 & 4.29 & 94.17 & 12.70 & 0.24 & 0.06 & 20.66 & 3.79 & 35.81 & 6.10 & 10.58 & 1.94 & 30.06 & 4.02 & 20.00 & 4.61 \\
\hline & LOW & 22.41 & 4.68 & 93.28 & 12.65 & 0.23 & 0.04 & 21.00 & 3.02 & 32.03 & 3.75 & 10.29 & 1.25 & 38.86 & 26.28 & 21.13 & 3.67 \\
\hline \multirow{4}{*}{$\begin{array}{c}\text { Background } \\
\text { Value }\end{array}$} & Total & 22.84 & 4.86 & 100.56 & 23.38 & 0.28 & 0.21 & 28.75 & 17.75 & 36.82 & 8.88 & 10.24 & 1.86 & 32.44 & 12.45 & 21.43 & 5.80 \\
\hline & Qinghai & 22.2 & & 80.3 & & 0.14 & & 20.9 & & 70.1 & & 10.1 & & 29.6 & & 14.0 & \\
\hline & Tibet & 21.9 & & 74.0 & & 0.08 & & 29.1 & & 76.6 & & 11.8 & & 32.1 & & 19.7 & \\
\hline & Mean & 22.1 & & 77.2 & & 0.11 & & 25.0 & & 73.4 & & 11.0 & & 30.9 & & 16.9 & \\
\hline
\end{tabular}


Table 5. Descriptive Statistics of Trace Element Concentrations in Grasses (mg/kg).

\begin{tabular}{|c|c|c|c|c|c|c|c|c|c|c|c|c|c|c|c|c|c|}
\hline & & \multicolumn{2}{|c|}{$\mathrm{Cu}-\mathrm{G}$} & \multicolumn{2}{|c|}{ Zn-G } & \multicolumn{2}{|c|}{ Cd-G } & \multicolumn{2}{|c|}{ Pb-G } & \multicolumn{2}{|c|}{$\mathrm{Cr}-\mathrm{G}$} & \multicolumn{2}{|c|}{ Co-G } & \multicolumn{2}{|c|}{ Ni-G } & \multicolumn{2}{|c|}{ As-G } \\
\hline & & Mean & S.D. & Mean & S.D. & Mean & S.D. & Mean & S.D. & Mean & S.D. & Mean & S.D. & Mean & S.D. & Mean & S.D. \\
\hline \multirow{5}{*}{ DIST } & $0 \mathrm{~m}$ & 9.38 & 5.41 & 33.89 & 14.29 & 0.10 & 0.15 & 3.49 & 5.88 & 15.61 & 16.07 & 0.64 & 1.05 & 4.41 & 4.94 & 1.64 & 2.57 \\
\hline & $10 \mathrm{~m}$ & 10.29 & 5.32 & 32.98 & 15.06 & 0.06 & 0.09 & 2.65 & 4.86 & 15.67 & 19.07 & 0.76 & 1.34 & 4.77 & 5.69 & 1.77 & 2.68 \\
\hline & $30 \mathrm{~m}$ & 10.29 & 5.63 & 31.16 & 12.45 & 0.05 & 0.06 & 1.90 & 3.24 & 14.98 & 14.01 & 0.55 & 0.72 & 4.08 & 3.52 & 1.30 & 1.41 \\
\hline & $50 \mathrm{~m}$ & 9.24 & 3.76 & 28.10 & 10.48 & 0.04 & 0.04 & 1.25 & 1.93 & 13.46 & 13.01 & 0.45 & 0.69 & 3.46 & 2.82 & 1.04 & 1.23 \\
\hline & $100 \mathrm{~m}$ & 10.04 & 7.26 & 31.22 & 15.15 & 0.04 & 0.05 & 1.01 & 1.50 & 11.09 & 7.54 & 0.36 & 0.56 & 3.45 & 2.80 & 0.90 & 1.04 \\
\hline \multirow{4}{*}{$\begin{array}{c}\text { LAND } \\
\text { COVER }\end{array}$} & Level 1 & 8.33 & 3.62 & 33.76 & 11.66 & 0.03 & 0.05 & 1.23 & 3.03 & 10.87 & 10.95 & 0.40 & 0.98 & 3.66 & 4.51 & 1.15 & 2.28 \\
\hline & Level 2 & 11.59 & 7.41 & 33.31 & 16.87 & 0.09 & 0.13 & 4.18 & 5.51 & 22.43 & 19.56 & 0.88 & 0.99 & 5.12 & 4.38 & 1.93 & 1.81 \\
\hline & Level 3 & 10.49 & 5.05 & 25.14 & 9.99 & 0.06 & 0.08 & 0.99 & 1.02 & 10.18 & 5.87 & 0.42 & 0.52 & 3.40 & 2.40 & 0.94 & 0.92 \\
\hline & $\mathrm{HIGH}$ & 10.86 & 6.89 & 36.69 & 16.89 & 0.09 & 0.11 & 4.01 & 5.53 & 19.75 & 20.51 & 0.85 & 1.26 & 5.23 & 5.84 & 1.96 & 2.74 \\
\hline \multirow[t]{5}{*}{ VOLUME } & MEDIUM & 9.16 & 4.46 & 30.07 & 9.68 & 0.03 & 0.07 & 0.63 & 0.91 & 9.55 & 5.37 & 0.31 & 0.45 & 3.18 & 1.77 & 0.83 & 0.74 \\
\hline & LOW & 9.22 & 3.72 & 21.73 & 3.02 & 0.02 & 0.00 & 1.15 & 1.03 & 13.12 & 4.11 & 0.48 & 0.57 & 3.41 & 2.33 & 1.15 & 1.06 \\
\hline & Ac.S. & 5.17 & 1.55 & 14.48 & 3.72 & 0.00 & 0.00 & 0.11 & 0.16 & 7.38 & 3.29 & 0.01 & 0.02 & 1.15 & 0.38 & 0.43 & 0.25 \\
\hline & A.N. & 15.26 & 7.18 & 39.29 & 17.36 & 0.13 & 0.14 & 6.90 & 6.44 & 34.31 & 19.38 & 1.64 & 1.39 & 8.93 & 6.25 & 3.59 & 3.10 \\
\hline & Ar.S. & 18.94 & 2.84 & 27.85 & 4.72 & 0.16 & 0.13 & 2.14 & 0.51 & 14.91 & 2.52 & 1.00 & 0.24 & 4.11 & 0.60 & 1.75 & 0.35 \\
\hline \multirow{7}{*}{$\begin{array}{c}\text { PLANT } \\
\text { TYPE }\end{array}$} & C.M. & 7.98 & 2.36 & 39.03 & 14.77 & 0.00 & 0.01 & 0.29 & 0.34 & 9.71 & 7.17 & 0.08 & 0.14 & 2.55 & 0.94 & 0.45 & 0.30 \\
\hline & I.L. & 4.59 & 0.40 & 11.16 & 1.89 & 0.04 & 0.02 & 0.14 & 0.32 & 2.85 & 1.52 & 0.00 & 0.00 & 0.17 & 0.15 & 0.19 & 0.22 \\
\hline & K.M. & 7.48 & 2.27 & 27.30 & 8.44 & 0.04 & 0.06 & 1.13 & 1.90 & 11.21 & 6.09 & 0.23 & 0.26 & 2.49 & 1.27 & 0.75 & 0.52 \\
\hline & O.W. & 5.15 & 0.75 & 30.26 & 7.00 & 0.04 & 0.03 & 0.89 & 0.55 & 4.83 & 1.36 & 0.03 & 0.04 & 1.54 & 0.27 & 0.18 & 0.19 \\
\hline & O.O. & 10.19 & 3.45 & 29.86 & 6.20 & 0.03 & 0.02 & 1.12 & 1.24 & 9.60 & 5.69 & 0.54 & 0.63 & 4.89 & 2.02 & 1.24 & 1.18 \\
\hline & S.C. & 7.45 & 1.41 & 42.75 & 3.96 & 0.03 & 0.01 & 0.45 & 0.63 & 3.69 & 0.90 & 0.10 & 0.08 & 0.80 & 0.19 & 0.38 & 0.12 \\
\hline & Total & 9.85 & 5.49 & 31.47 & 13.48 & 0.05 & 0.09 & 2.06 & 3.89 & 14.16 & 14.26 & 0.55 & 0.91 & 4.03 & 4.07 & 1.33 & 1.91 \\
\hline
\end{tabular}


As shown in Table 5, the concentrations of each trace element in soils decreased with the increase of roadside distance, as well as $\mathrm{Zn}, \mathrm{Cd}$ and $\mathrm{Pb}$ in grasses. However the concentrations of $\mathrm{Cu}, \mathrm{Cr}, \mathrm{Co}$, $\mathrm{Ni}$ and $\mathrm{As}$ in grasses had the highest value at $10 \mathrm{~m}$ to road edge. It can be inferred that the concentrations of trace elements in the soil at the sites, where the concentrations of the corresponding trace element in grasses are the maximum value, is the most befitting concentration for grasses to absorb. With consideration of the background values of the trace elements in soil [19], it can be inferred that trace elements have already been accumulated in the roadside soil. Except for $\mathrm{Cr}, \mathrm{Co}, \mathrm{Ni}$ in soil and $\mathrm{Zn}$ in grasses, concentrations of other trace elements were highest when the land cover is meadow with high sand content. Additionally, for both soil and grass, concentrations were the highest when the traffic volume was at the "HIGH" level except for $\mathrm{Cu}, \mathrm{Co}$ and $\mathrm{Ni}$ in soils. But there were no significant difference in the concentrations when the traffic volume was MEDIUM and LOW.

For the different grass species, the concentrations of $\mathrm{Pb}, \mathrm{Cr}, \mathrm{Co}, \mathrm{Ni}$ and $\mathrm{As}$ in Anaphalis nepalensis were the highest among the nine grass species, Artemisia sphaerocephala showed the highest concentrations of $\mathrm{Cu}$ and $\mathrm{Cd}$, and the concentration of $\mathrm{Zn}$ in Stellera chamaejasme was the highest. However, the concentrations of $\mathrm{Cu}, \mathrm{Zn}$ and $\mathrm{Cd}$ in Anaphalis nepalensis and $\mathrm{Zn}$ in Carex moorcroftii are also considerable.

The total mean values of the eight trace elements in grasses are $\mathrm{Cu}(9.85 \mathrm{mg} / \mathrm{kg}), \mathrm{Zn}(31.47 \mathrm{mg} / \mathrm{kg})$, $\mathrm{Cd}(0.05 \mathrm{mg} / \mathrm{kg}), \mathrm{Pb}(2.06 \mathrm{mg} / \mathrm{kg}), \mathrm{Cr}(14.16 \mathrm{mg} / \mathrm{kg}), \mathrm{Co}(0.55 \mathrm{mg} / \mathrm{kg}), \mathrm{Ni}(4.03 \mathrm{mg} / \mathrm{kg})$ and As $(1.33 \mathrm{mg} / \mathrm{kg})$. Generally, the concentrations of a trace element in hyperacumulators are 100 times higher than that in ordinary plants. Currently, a plant with its above-ground-tissues containing more than $100 \mathrm{mg} / \mathrm{kg} \mathrm{Cd}, 1,000 \mathrm{mg} / \mathrm{kg} \mathrm{Cu}, 1,000 \mathrm{mg} / \mathrm{kg} \mathrm{Pb}, 1,000 \mathrm{mg} / \mathrm{kg} \mathrm{Co}, 1,000 \mathrm{mg} / \mathrm{kg} \mathrm{Ni}$, or $10,000 \mathrm{mg} / \mathrm{kg} \mathrm{Zn}$ can be called as a hyperaccumulator [9]. Accordingly, none of the nine grasses in this research can be recognized as hyperaccumulators.

\subsection{MANOVA of Trace Element Concentrations and Independent Factors}

A MANOVA is used to investigate the effects of different levels of DIST, LAND COVER, VOLUME on the trace elements in soil (see in Table 6) and the influences of different levels of DIST, LAND COVER, VOLUME, PLANT TYPE on the concentrations of trace elements in grasses (see in Table 7). The hypothesis testing in the analyses is based on the 0.1 and 0.05 significance levels. The results indicate that the factors affect the concentrations of the eight trace elements in various degrees.

For soil, DIST has significant effects on the concentrations of $\mathrm{Cu}(p<0.01), \mathrm{Zn}(p<0.01)$, $\mathrm{Cd}(p<0.01)$, and $\mathrm{Pb}(p<0.01)$, LAND COVER significantly affects the concentrations of $\mathrm{Cu}(p<0.01), \mathrm{Zn}(p<0.01), \mathrm{Pb}(p<0.05)$, and $\mathrm{As}(p<0.01)$, and VOLUME significantly influences the concentrations of $\mathrm{Cu}(p<0.01), \mathrm{Zn}(p<0.05), \mathrm{Pb}(p<0.01), \mathrm{Cr}(p<0.05)$, and $\mathrm{Ni}(p<0.05)$. The sums of the $F$ values in the MANOVA stand for the significance of the total effect of a factor on various trace element concentrations. For soil, significance order of the factors is VOLUME $(F=44.964)>\operatorname{LAND}$ COVER $(F=34.082)>$ DIST $(F=25.530)$, illustrating that the most significant factor influencing metal concentrations in soil is VOLUME.

For grasses, PLANT TYPE has a significant influence on all the eight trace elements $(p<0.01)$, which means that the concentrations of trace elements are distinct in the different grass species. Furthermore, DIST has significant effects on $\mathrm{Cd}(p<0.05)$ and $\mathrm{Pb}(p<0.05)$, LAND COVER 
significantly affects the concentration of $\mathrm{Cd}(p<0.05), \mathrm{Pb}(p<0.01), \mathrm{Cr}(p<0.01), \mathrm{Co}(p<0.01)$, $\mathrm{Ni}(p \leq 0.05)$ and As $(p<0.01)$, and VOLUME significantly influences the concentrations of $\mathrm{Zn}(p<0.01), \mathrm{Cd}(p<0.05), \mathrm{Pb}(p<0.01), \mathrm{Cr}(p<0.05)$ and $\mathrm{Ni}(p<0.01)$. For grass, significance order of the factors is PLANT TYPE $(F=90.041)>$ LAND COVER $(F=37.894)>$ VOLUME $(F=37.148)>\operatorname{DIST}(F=12.13)$, so that the most significant factor influencing metal concentrations in grass is PLANT TYPE.

Table 6. MANOVA results of trace element concentrations for Soil Samples.

\begin{tabular}{cccccccccc}
\hline \multirow{2}{*}{ Source } & \multicolumn{4}{c}{ DIST } & \multicolumn{4}{c}{ LAND COVER } & \multicolumn{3}{c}{ VOLUME } \\
\cline { 2 - 10 } & df & F & Sig. & df & F & Sig. & df & F & Sig. \\
\hline $\mathrm{Cu}-\mathrm{S}$ & 4 & 6.955 & $0.000 * *$ & 2 & 10.338 & $0.000 * *$ & 2 & 8.147 & $0.001 * *$ \\
$\mathrm{Zn}-\mathrm{S}$ & 4 & 4.396 & $0.003 * *$ & 2 & 5.100 & $0.008 * *$ & 2 & 4.496 & $0.014 *$ \\
$\mathrm{Cd}-\mathrm{S}$ & 4 & 4.119 & $0.004 * *$ & 2 & 2.267 & 0.109 & 2 & 2.309 & 0.105 \\
$\mathrm{~Pb}-\mathrm{S}$ & 4 & 6.958 & $0.000 * *$ & 2 & 4.720 & $0.011 *$ & 2 & 18.649 & $0.000 * *$ \\
$\mathrm{Cr}-\mathrm{S}$ & 4 & 0.357 & 0.838 & 2 & 0.969 & 0.383 & 2 & 4.167 & $0.019 *$ \\
$\mathrm{Co}-\mathrm{S}$ & 4 & 1.393 & 0.243 & 2 & 2.528 & 0.085 & 2 & 2.334 & 0.103 \\
$\mathrm{Ni}-\mathrm{S}$ & 4 & 0.959 & 0.434 & 2 & 1.014 & 0.367 & 2 & 3.481 & $0.035 *$ \\
$\mathrm{As}-\mathrm{S}$ & 4 & 0.393 & 0.814 & 2 & 7.146 & $0.001 * *$ & 2 & 1.381 & 0.257 \\
\hline
\end{tabular}

* Significant at $p \leq 0.05 ; * *$ Significant at $p \leq 0.01$.

Table 7. MANOVA results of trace element concentrations for Grass Samples.

\begin{tabular}{|c|c|c|c|c|c|c|c|c|c|c|c|c|}
\hline \multirow{2}{*}{ Source } & \multicolumn{3}{|c|}{ DIST } & \multicolumn{3}{|c|}{ LAND COVER } & \multicolumn{3}{|c|}{ VOLUME } & \multicolumn{3}{|c|}{ PLANT TYPE } \\
\hline & df & $\mathbf{F}$ & Sig. & df & $\mathbf{F}$ & Sig. & df & $\mathbf{F}$ & Sig. & df & $\mathbf{F}$ & Sig. \\
\hline $\mathrm{Cu}-\mathrm{G}$ & 4 & 0.365 & 0.833 & 2 & 2.925 & 0.059 & 2 & 2.103 & 0.129 & 8 & 13.962 & $0.000 * *$ \\
\hline $\mathrm{Zn}-\mathrm{G}$ & 4 & 0.989 & 0.418 & 2 & 0.532 & 0.590 & 2 & 11.157 & $0.000 * *$ & 8 & 7.475 & $0.000 * *$ \\
\hline $\mathrm{Cd}-\mathrm{G}$ & 4 & 3.206 & $0.017 *$ & 2 & 3.723 & $0.028 *$ & 2 & 4.611 & $0.013 *$ & 8 & 6.836 & $0.000 * *$ \\
\hline $\mathrm{Pb}-\mathrm{G}$ & 4 & 3.097 & $0.020 *$ & 2 & 5.437 & $0.006 * *$ & 2 & 5.147 & $0.008 * *$ & 8 & 9.731 & $0.000 * *$ \\
\hline $\mathrm{Cr}-\mathrm{G}$ & 4 & 1.039 & 0.392 & 2 & 11.863 & $0.000 * *$ & 2 & 3.411 & $0.038 *$ & 8 & 17.516 & $0.000 * *$ \\
\hline $\mathrm{Co}-\mathrm{G}$ & 4 & 1.166 & 0.332 & 2 & 5.173 & $0.008 * *$ & 2 & 2.149 & 0.123 & 8 & 10.958 & $0.000 * *$ \\
\hline Ni-G & 4 & 0.871 & 0.485 & 2 & 3.105 & $0.050 *$ & 2 & 5.998 & $0.004 * *$ & 8 & 13.878 & $0.000 * *$ \\
\hline As-G & 4 & 1.397 & 0.242 & 2 & 5.136 & $0.008 * *$ & 2 & 2.572 & 0.082 & 8 & 9.685 & $0.000 * *$ \\
\hline
\end{tabular}

* Significant at $p \leq 0.05 ; * *$ Significant at $p \leq 0.01$.

\subsection{Interrelationship Analysis of Trace Elements}

Tables 8 and 9 summarize the correlation analysis of $\mathrm{Cu}, \mathrm{Zn}, \mathrm{Cd}, \mathrm{Pb}, \mathrm{Cr}, \mathrm{Co}, \mathrm{Ni}$ and $\mathrm{As}$ concentrations in soils and grasses, respectively. The trace elements $(\mathrm{Cu}-\mathrm{Zn}, \mathrm{Cu}-\mathrm{Cd}, \mathrm{Cu}-\mathrm{Pb}, \mathrm{Cu}-\mathrm{Cr}$, $\mathrm{Cu}-\mathrm{Co}, \mathrm{Cu}-\mathrm{As}, \mathrm{Zn}-\mathrm{Cd}$, Zn-Pb, Zn-Co, Zn-As, Cd-Pb, Cd-As, Pb-Cr, Pb-As, Cr-Co, Cr-Ni, Cr-As, Co-Ni, Co-As, As-Ni ) in soil show significant correlation with each other at the 0.01 or 0.05 levels.

Trace elements in soil can be geogenic or originated from anthropogenic inputs [1,21,22]. The significant correlations indicate the homology of the metal(loid)s pollution source. Since there is no industrial pollution at the research area, traffic is the main source of the trace elements in the soil $[16,17,23]$. Therefore, the significant correlation proved that the trace elements in roadside soil come from the traffic contamination. 
As shown in Table 7, the concentrations in grasses of every two trace elements had significant correlation with each other at the 0.01 level. This makes a clear explanation that all the eight trace elements in the nine grass species are homological. Similar to the previous study [8,17,22,23], traffic is the main source of contamination along the road, so the high concentration of trace elements in grasses are mainly influenced by the traffic through uptake from the soil by roots and from the dust by leaves [1].

Table 8. Correlation analysis of the metal(loid) concentrations in soil.

\begin{tabular}{|c|c|c|c|c|c|c|c|c|}
\hline Pearson Correlation & $\mathrm{Cu}-\mathrm{S}$ & Zn-S & Cd-S & $\mathbf{P b}-\mathrm{S}$ & $\mathrm{Cr}-\mathrm{S}$ & Co-S & Ni-S & As-S \\
\hline $\mathrm{Cu}-\mathrm{S}$ & 1.000 & $0.531^{* *}$ & $0.423^{* *}$ & $0.392^{* *}$ & $0.294^{* *}$ & $0.568^{* *}$ & 0.059 & $0.393^{* \prime}$ \\
\hline $\mathrm{Zn}-\mathrm{S}$ & $0.531^{* *}$ & 1.000 & $0.742^{* *}$ & $0.828^{* *}$ & 0.166 & $0.275^{* *}$ & 0.003 & $0.431^{* *}$ \\
\hline $\mathrm{Cd}-\mathrm{S}$ & $0.423^{* *}$ & $0.742^{* *}$ & 1.000 & $0.873^{* *}$ & 0.001 & 0.129 & -0.071 & $0.344^{* *}$ \\
\hline $\mathrm{Pb}-\mathrm{S}$ & $0.392^{* *}$ & $0.828^{* *}$ & $0.873^{* *}$ & 1.000 & $0.202^{*}$ & 0.193 & 0.027 & $0.409^{* *}$ \\
\hline $\mathrm{Cr}-\mathrm{S}$ & $0.294^{* *}$ & 0.166 & 0.001 & $0.202^{*}$ & 1.000 & $0.434^{* * *}$ & $0.490^{* *}$ & $0.288^{* *}$ \\
\hline $\mathrm{Co}-\mathrm{S}$ & $0.568^{* *}$ & $0.275^{* *}$ & 0.129 & 0.193 & $0.434^{* *}$ & 1.000 & $0.323^{* *}$ & $0.626^{* *}$ \\
\hline $\mathrm{Ni}-\mathrm{S}$ & 0.059 & 0.003 & 0.071 & 0.027 & $0.490 * *$ & $0.323^{* *}$ & 1.000 & $0.210^{*}$ \\
\hline As-S & $0.393^{* *}$ & $0.431^{* *}$ & $0.344^{* *}$ & $0.409^{* *}$ & $0.288^{* *}$ & $0.626^{* *}$ & $0.210^{*}$ & 1.000 \\
\hline
\end{tabular}

$* *$ Correlation is significant at the 0.01 level (2-tailed); * Correlation is significant at the 0.05 level (2-tailed).

Table 9. Correlation Analysis of the metal(loid) Concentrations in grasses.

\begin{tabular}{|c|c|c|c|c|c|c|c|c|}
\hline $\begin{array}{c}\text { Pearson } \\
\text { Correlation }\end{array}$ & $\mathrm{Cu}-\mathbf{G}$ & Zn-G & Cd-G & Pb-G & Cr-G & Co-G & Ni-G & As-G \\
\hline $\mathrm{Cu}-\mathrm{G}$ & 1.000 & $0.528^{* * *}$ & $0.656^{* *}$ & $0.627^{\text {*** }}$ & $0.622^{* * *}$ & $0.590^{* * *}$ & $0.618^{* * *}$ & $0.540^{* * *}$ \\
\hline Zn-G & $0.528^{* *}$ & 1.000 & $0.490^{* * *}$ & $0.529^{* *}$ & $0.409^{* * *}$ & $0.443^{\text {*** }}$ & $0.515^{* *}$ & $0.426^{\text {*** }}$ \\
\hline Cd-G & $0.656^{* *}$ & $0.490^{* *}$ & 1.000 & $0.777^{\text {** }}$ & $0.643^{\text {*** }}$ & $0.566^{* * *}$ & $0.565^{\text {** }}$ & $0.543^{\text {** }}$ \\
\hline $\mathrm{Pb}-\mathrm{G}$ & $0.627^{* * *}$ & $0.529^{* * *}$ & $0.777^{* * *}$ & 1.000 & $0.873^{\text {** }}$ & $0.829^{* * *}$ & $0.837^{\text {** }}$ & $0.828^{* * *}$ \\
\hline $\mathrm{Cr}-\mathrm{G}$ & $0.622^{* * *}$ & $0.409^{* * *}$ & $0.643^{\text {*** }}$ & $0.873^{* *}$ & 1.000 & $0.850^{* * *}$ & $0.841^{* * *}$ & $0.817^{* * *}$ \\
\hline Co-G & $0.590^{* *}$ & $0.443^{* *}$ & $0.566^{* *}$ & $0.829^{* * *}$ & $0.850^{* * *}$ & 1.000 & $0.948^{* * *}$ & $0.979^{* * *}$ \\
\hline $\mathrm{Ni}-\mathrm{G}$ & $0.618^{\text {** }}$ & $0.515^{* *}$ & $0.565^{\text {** }}$ & $0.837^{\text {** }}$ & $0.841^{* * *}$ & $0.948^{* * *}$ & 1.000 & $0.948^{* * *}$ \\
\hline As-G & $0.540^{\text {** }}$ & $0.426^{* *}$ & $0.543^{* * *}$ & $0.828^{\text {** }}$ & $0.817^{\text {** }}$ & $0.979^{* * *}$ & $0.948^{* *}$ & 1.000 \\
\hline
\end{tabular}

As in Yan et al.'s research [8], the eight trace elements were mostly concentrated within $30 \mathrm{~m}$ from the road. According to Zhang et al. [20], to further verify the interrelationship of the eight trace elements in soil within $30 \mathrm{~m}$ from the roadside and their homology, principal component analysis and cluster analysis were implemented. As a result, two components (Components 1 and 2) were extracted, where Component 1 is related to $\mathrm{Cu}, \mathrm{Zn}, \mathrm{Pb}$, and $\mathrm{Cd}$, meanwhile Component 2 is related to $\mathrm{As}, \mathrm{Co}, \mathrm{Cr}$, and $\mathrm{Ni}$. The scatter plot of factors 1 and 2 and the dendrogram in Figure 3 showed the interrelationships among the eight trace elements in soils, indicating that $\mathrm{Co}, \mathrm{As}, \mathrm{Cr}$ and $\mathrm{Ni}$ are geogenic, while $\mathrm{Cu}, \mathrm{Zn}, \mathrm{Pb}$, and $\mathrm{Cd}$ are mainly from the traffic source, which is almost the same with studies of Shi [24], Nabulo [25] and Viard [26]. 
Figure 3. Scatter plots and cluster tree of trace elements in soil.
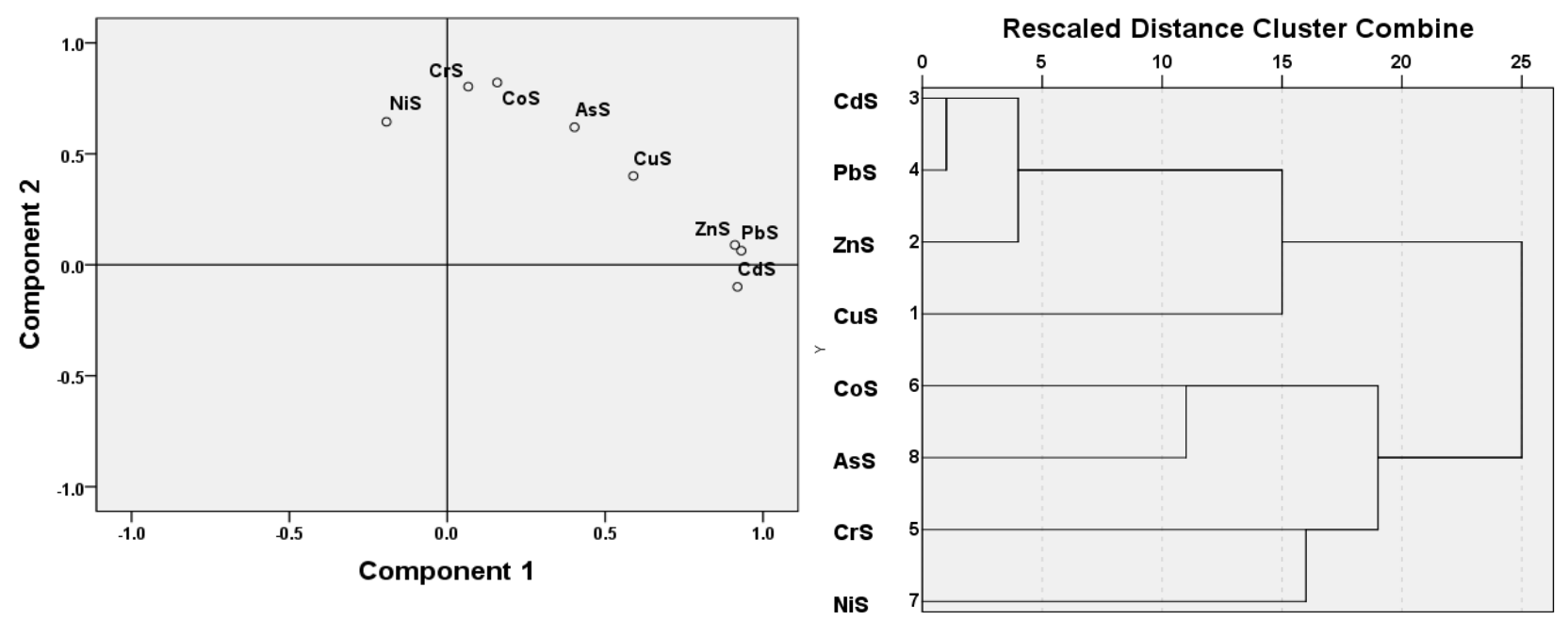

\subsection{Transfer Factor of Trace element from Soil to Grasses}

Table 10 summarizes the descriptive statistical results of Transfer Factor (TF) of the trace elements from soil to grass. According to the previous research results of TF [18,22,27,28], the value range in most cases is $0-1$. In Yan's study in Nepal [22], the TF value of Cd is above 1. In this study, the TF values are all below 1 .

In total, the values of the trace element TFs are in the following order: $\mathrm{Cu}>\mathrm{Cr}>\mathrm{Zn}>\mathrm{Cd}>\mathrm{Ni}>$ $\mathrm{Pb}=\mathrm{As}>\mathrm{Co}$. In Yan's study [22] the order of TFs of the grasses in Nepal is $\mathrm{Zn}>\mathrm{Cu}>\mathrm{Pb}$. It can be inferred that TFs varies from one grass species to another. For Achnatherum splendens, the order is $\mathrm{Cr}>\mathrm{Cu}>\mathrm{Zn}>\mathrm{Ni}>\mathrm{As}>\mathrm{Cd}>\mathrm{Pb}=\mathrm{Co}$, for Anaphalis nepalensis, the order is $\mathrm{Cr}>\mathrm{Cu}>\mathrm{Cd}>\mathrm{Zn}>$ $\mathrm{Ni}>\mathrm{Pb}>\mathrm{As}=\mathrm{Co}$, however, for Carex moorcroftii, the order is $\mathrm{Zn}>\mathrm{Cu}>\mathrm{Cr}>\mathrm{Ni}>\mathrm{As}>\mathrm{Cd}>\mathrm{Pb}>\mathrm{Co}$.

Furthermore, Anaphalis nepalensis has the highest $\mathrm{TF}$ values for $\mathrm{Cu}, \mathrm{Pb}, \mathrm{Cr}, \mathrm{Co}, \mathrm{Ni}$ and $\mathrm{As}$, Artemisia sphaerocephala has the highest TF values for Cd, while Carex moorcroftii and Stellera chamaejasme have the highest TF values for $\mathrm{Zn}$.

Furthermore, the factors of DIST and LAND COVER do not show a consistent influence on TF for the trace elements. However under the high level of traffic volume, the TFs are higher than those under lower level of traffic volume. 
Table 10. Descriptive statistical results of Transfer Factor (TF) of grass-soil trace element concentrations.

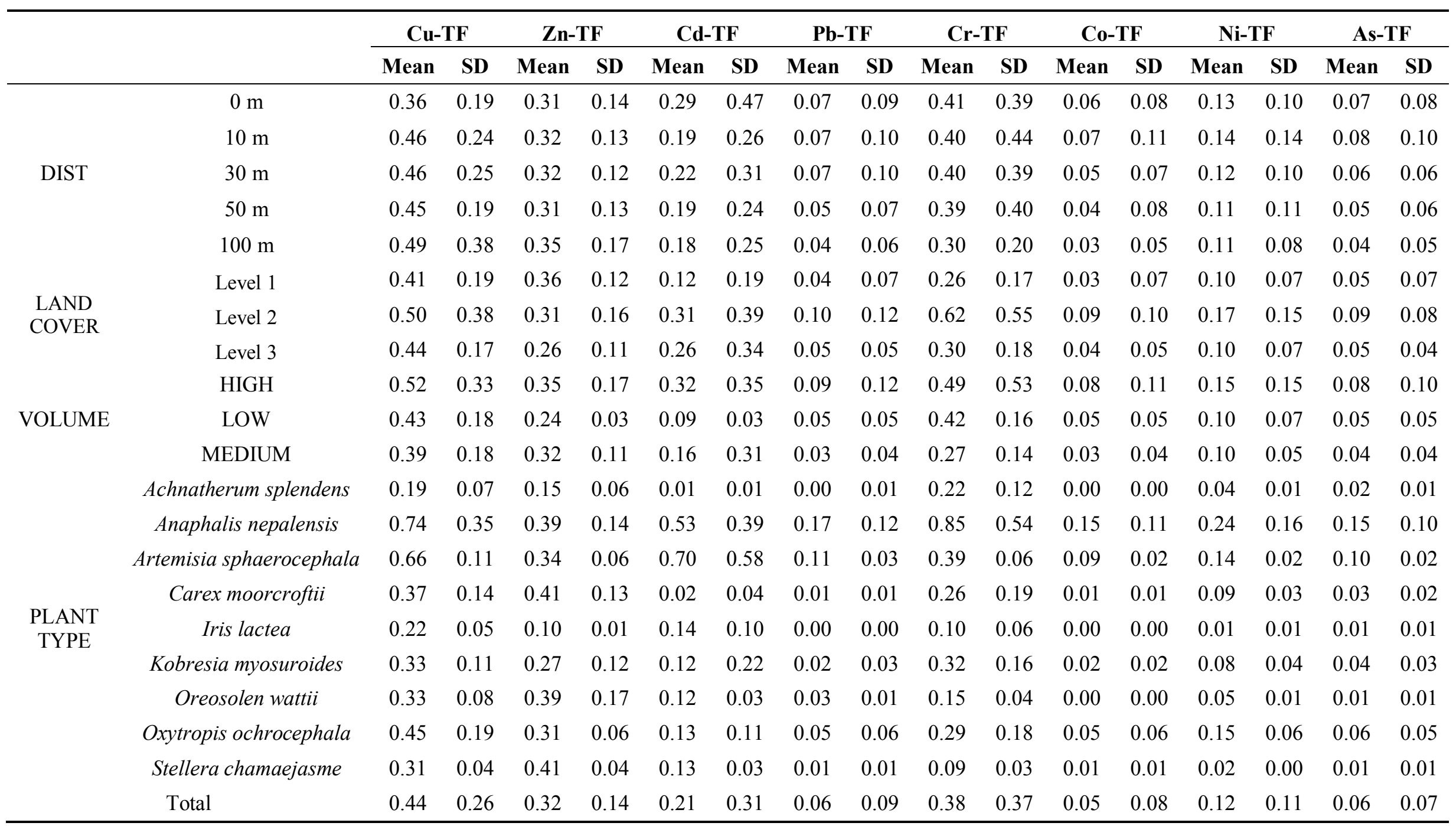




\section{Conclusions}

Trace elements $(\mathrm{Cu}, \mathrm{Zn}, \mathrm{Cd}, \mathrm{Pb}, \mathrm{Cr}, \mathrm{Co}, \mathrm{Ni}, \mathrm{As})$ in soils and plants along the G109, S308 and G214 in the Qinghai-Tibet Plateau were investigated in this research. It was found that soil concentrations of $\mathrm{Cu}, \mathrm{Zn}, \mathrm{Pb}$ and $\mathrm{Cd}$ were mostly affected by the road traffic volume along the research road segments. As the research of Legret et al. [29], in roadside soil, $\mathrm{Pb}$ mostly comes from wear of the brake linings and the off gas of the vehicles, $\mathrm{Cu}$ almostly comes from the brake linings, and the wear and tear of the brake linings and the tires contribute evenly to $\mathrm{Cd}$ and $\mathrm{Zn}$ levels. The concentration of $\mathrm{Pb}$ in this research is lower than that along the researched roadside in Beijng [6] proving that the traffic volume in Qinghai-Tibet was lower than in Beijing. To the contrary, the higher concentrations of $\mathrm{Zn}$ and $\mathrm{Cd}$ in this research indicated that the condition of the road surface in Qinghai-Tibet was worse than that in Beijing, so that the tires were more worn. Considering the frequent congestion in Beijing, its higher concentration of $\mathrm{Cu}$ than that in Qinghai-Tibet is reasonable.

Transfer factors (TF) of the eight trace elements that represent their bioavailability vary with different grass species. Among the nine grass species, Anaphalis nepalensis ( $\mathrm{Pb}, \mathrm{Cr}, \mathrm{Co}, \mathrm{Ni}, \mathrm{As}, \mathrm{Cu}$, $\mathrm{Zn}$ and $\mathrm{Cd})$, Artemisia sphaerocephala $(\mathrm{Cu}$ and $\mathrm{Cd})$, Stellera chamaejasme $(\mathrm{Zn})$ and Carex moorcroftii (Zn) were better transfer plants, but haven't reached the level of hyperaccumulators.

The results of this study are preliminary, but the relationship between $\mathrm{Cu}, \mathrm{Zn}, \mathrm{Pb}, \mathrm{Cd}$ and traffic volume were verified, and the relatively high ability of Anaphalis nepalensis to transfer trace elements from soils were identified. They can serve as the bases for further study on long-term monitoring of trace elements accumulation in roadside soil and grasses, and on the relationship between traffic and roadside ecology, under the sensitive and vulnerable environment of the Qinghai-Tibet plateau.

\section{Acknowledgments}

The study was financially supported by Program for New Century Excellent Talents in University (NCET-11-0570) and the Hundred Talent Program of Chinese Academy of Sciences (CAS).

\section{Conflicts of Interest}

The authors declare no conflict of interest.

\section{References}

1. Wiseman, C.L.S.; Zereini, F.; Püttmann, W. Traffic-related trace element fate and uptake by plants cultivated in roadside soils in Toronto, Canada. Sci. Total Environ. 2013, 442, 86-95.

2. Markert, B.; Wuenschmann, S.; Fraenzle, S.; Figueiredo, A.M.G.; Ribeiro, A.P.; Wang, M. Bioindication of atmospheric trace metals-With special references to megacities. Environ. Pollut. 2011, 159, 1991-1995.

3. Khan, S.; Khan, M.; Rehman, S. Lead and cadmium contamination of different roadside soils and plants in Peshawar City, Pakistan. Pedosphere 2011, 21, 351-357.

4. Yassoglou, N.; Kosmas, C.; Asimakopoulos, J.; Kallianou, C. Heavy metal contamination of roadside soils in the Greater Athens area. Environ. Pollut. 1987, 47, 293-304. 
5. Liu, H.; Chen, L.-P.; Ai, Y.-W.; Yang, X.; Yu, Y.-H.; Zuo, Y.-B.; Fu, G.-Y. Heavy metal contamination in soil alongside mountain railway in Sichuan, China. Environ. Monit. Assess. 2009, 152, 25-33.

6. Chen, X.; Xia, X.; Zhao, Y.; Zhang, P. Heavy metal concentrations in roadside soils and correlation with urban traffic in Beijing, China. J. Hazard. Mater. 2010, 181, 640-646.

7. Wilcke, W.; Muller, S.; Kanchanakool, N.; Zech, W. Urban soil contamination in Bangkok: Heavy metal and aluminium partitioning in topsoils. Geoderma 1998, 86, 211-228.

8. Yan, X.; Gao, D.; Zhang, F.; Zeng, C.; Xiang, W.; Zhang, M. Relationships between heavy metal concentrations in roadside topsoil and distance to road edge based on field observations in the Qinghai-Tibet Plateau, China. Int. J. Environ. Res. Public health 2013, 10, 762-775.

9. Chen, Y. Chemical Analysis of Soil Heavy Metal Pollution to Plant; Science Press: Beijing, China, 2008.

10. Jeffrey, D.W. Soil-Plant Relationships. An Ecological Approach; Croom Helm: Kent, UK, 1987.

11. Baker, A.J.M.; Brooks, R. Terrestrial higher plants which hyperaccumulate metallic elements. A review of their distribution, ecology and phytochemistry. Biorecovery 1989, 1, 81-126.

12. Salt, D.E.; Blaylock, M.; Kumar, N.P.B.A.; Dushenkov, V.; Ensley, B.D.; Chet, I.; Raskin, I. Phytoremediation: A novel strategy for the removal of toxic metals from the environment using plants. Nat. Biotechnol. 1995, 13, 468-474.

13. Baker, A.J.M.; McGrath, S.P.; Reeves, R.D.; Smith, J.A.C. Metal hyperaccumulator plants: A review of the ecology and physiology of a biological resource for phytoremediation of metal-polluted soils. Phytoremediat. Contam. Soil Water 2000, 2000, 85-107.

14. Kang, S.; Zhang, Q. Scientific survey and monitoring of atmospheric pollution over the Tibetan Plateau (in Chinese). Chin. J. Nat. 2010, 32, 13-18.

15. Yao, T.; Thompson, L.G.; Mosbrugger, V.; Zhang, F.; Ma, Y.; Luo, T.; Xu, B.; Yang, X.; Joswiak, D.R.; Wang, W.; et al. Third pole environment (TPE). Environ. Dev. 2012, 3, 52-64.

16. Yan, X.; Zhang, F.; Gao, D.; Zeng, C.; Xiang,W.; Zhang, M. Accumulations of heavy metals in roadside soils close to Zhaling, Eling and Nam Co Lakes in the Tibetan Plateau. Int. J. Environ. Res. Public Health 2013, 10, 2384-2400.

17. Chojnacka, K.; Chojnacki, A.; Gorecka, H.; Gorecki, H. Bioavailability of heavy metals from polluted soils to plants. Sci. Total Environ. 2005, 337, 175-182.

18. Zhang, F.; Yan, X.; Zeng, C.; Zhang, M.; Shrestha, S.; Devkota, L.P.; Yao, T. Influence of traffic activity on heavy metal concentrations of roadside farmland soil in mountainous areas. Int. J. Environ. Res. Public Health 2012, 9, 1715-1731.

19. Department of Environment Protection of China. Background Values of Trace Elements in Soils of China; China Environmental Science Press: Beijing, China, 1990.

20. Zhang, H.; Wang, Z.; Zhang, Y.; Hu, Z. The effects of the Qinghai-Tibet railway on heavy metals enrichment in soils. Sci. Total Environ. 2012, 439, 240-248.

21. Zaharescu, D.G.; Hooda, P.S.; Soler, A.P.; Fernandez, J.; Burghelea, C.I. Trace metals and their source in the catchment of the high altitude Lake Respomuso, Central Pyrenees. Sci. Total Environ. 2009, 407, 3546-3553. 
22. Yan, X.; Zhang, F.; Zeng, C.; Zhang, M.; Devkota, L.P.; Yao, T. Relationship between heavy metal concentrations in soils and grasses of roadside farmland in Nepal. Int. J. Environ. Res. Public Health 2012, 9, 3209-3226.

23. Ho, Y.B.; Tai, K.M. Elevated levels of lead and other metals in roadside soil and grass and their use to monitor aerial metal depositions in Hong Kong. Environ. Pollut. 1988, 49, 37-51.

24. Shi, G.; Chen, Z,; Xu, S.; Zhang, J.; Wang, L.; Bi, C.; Teng, J. Potentially toxic metal contamination of urban soils and roadside dust in Shanghai, China. Environ. Pollut. 2008, 156, 251-260.

25. Nabulo, G.; Oryem-Origa, H.; Diamond, M. Assessment of lead, cadmium, and zinc contamination of roadside soils, surface films, and vegetables in Kampala City, Uganda. Environ. Res. 2006, $101,42-52$.

26. Viard, B.; Pihan, F.; Promeyrat, S.; Pihan, J.-C. Integrated assessment of heavy metal (Pb, Zn, $\mathrm{Cd}$ ) highway pollution: Bioaccumulation in soil, Graminaceae and land snails. Chemosphere 2004, 55, 1349-1359.

27. Puschenreiter, M.; Horak, O. Influence of different soil parameters on the transfer factor soil to plant of $\mathrm{Cd}, \mathrm{Cu}$ and $\mathrm{Zn}$ for wheat and rye. Bodenkultur 2000, 51, 3-10.

28. Panday, A.K.; Prinn, R.G. Diurnal cycle of air pollution in the Kathmandu Valley, Nepal: Observations. J. Geophys. Res. 2009, 114, doi:10.1029/2008JD009777.

29. Legret, M.; Pagotto, C. Evaluation of pollutant loadings in the runoff waters from a major rural highway. Sci. Total Environ. 1999, 235, 143-150.

(C) 2014 by the authors; licensee MDPI, Basel, Switzerland. This article is an open access article distributed under the terms and conditions of the Creative Commons Attribution license (http://creativecommons.org/licenses/by/3.0/). 